\title{
KARAKTERISTIK KIMIA TULANG IKAN GABUS (CHANNA STRIATA) DARI BOBOT BADAN BERBEDA
}

\author{
Rosmawati $^{1)}$, Abu Bakar Tawali ${ }^{2)}$, Metusalach $^{3)}$, Amran Laga $^{4)}$ \\ ${ }^{1)}$ Fakultas Perikanan dan Ilmu Kelautan Univeraitas Muhammadiyah Kendari, Kendari- \\ Indonesia \\ ${ }^{2)}$ Laboratorium Ilmu dan Teknologi Pangan, Fakultas Pertanian Univeritas Hasanuddin, \\ Makassar-Indonesia \\ ${ }^{3)}$ Laboratorium Teknologi Hasil Perikanan, Fakultas Ilmu Kelautan dan Perikanan \\ Univeritas Hasanuddin, Makassar-Indonesia \\ ${ }^{1)}$ Email: rosrossie.ummumuthe@gmail.com
}

\begin{abstract}
ABSTRAK
Tulang ikan termasuk bahan baku yang terdiri dari komponen organik dan non-organik (mineral) yang penting, dan termasuk produk sampingan utama dari industri perikanan dan budidaya. Penelitian ini bertujuan untuk mengkarakterisasi komponen organik dan anorganik yang terkandung dalam tulang ikan gabus. Sampel ikan gabus pada bobot yang berbeda diperoleh dari Bili Bili Dam, Gowa. Penelitian ini bersifat eksperimental di laboratorium menggunakan metode Experimental Design. Contoh tulang ikan untuk analisis proksimat, kadar kolagen, tingkat protein, kadar mineral dan fitur mikroskopis menggunakan tulang ikan segar dan liopilisasi. Hasil analisis menunjukkan bahwa kadar air dan kolagen ikan gabus cenderung menurun dengan bertambahnya bobot badan, sedangkan kadar lemak dan abu cenderung meningkat, tetapi protein relatif tidak berbeda. Gambar mikroskopis dari Scanning Electron Microscopy dan kandungan mineral berbasis tulang dapat menjadi informasi penting untuk penggunaan tulang ikan gabus yang lebih luas.
\end{abstract}

Kata kunci: Asam amino, kolagen, proksimat, SEM-EDS, tulang ikan gabus 


\section{PENDAHULUAN}

Populasi penduduk yang cenderung meningkat, dengan kondisis sosial ekonomi yang semakin baik sangat berdampak positif terhadap tingginya kebutuhan pangan dengan kualitas dan kuantitas yang layak. Akhir-akhir ini potensi pangan tidak hanya fokus pada pemenuhan kebutuhan sebagai bahan pangan pokok untuk memenuhi kebutuhan nutrisi, tetapi juga telah mulai dikembangkan ke arah pemanfaatan yang lebih luas dan lebih kompleks. Diperkirakan bahwa beberapa tahun kedepan seiring pertambahan penduduk, kebutuhan pangan akan semakin meningkat, sehingga akan mendorong dilakukannya pencarian berbagai sumber-sumber pangan baru yang dapat mensubstitusi kebutuhan konsumsi manusia dari sumber pangan yang telah ada sebelumnya. Salah satu sumber pangan masa depan adalah sisa hasil pengolahan produk pangan itu sendiri.

Produk perikanan adalah sumber pangan potensial yang cukup berkembang pesat, dengan keunggulan pada kandungan protein dan asam-asam lemak yang baik dan aman untuk kesehatan. Salah satu hasil perikanan yang akhir-akhir ini banyak mendapat perhatian adalah ikan gabus (Channa striata). Ikan gabus termasuk ikan karnivora yang hidup di air tawar, mudah berkembang biak dan survive pada kondisi lingkungan sedikit air. Saat ini, ikan gabus telah menjadi produk makanan kesehatan dengan kandungan protein albumin yang secara ilmiah terbukti berfungsi dalam proses penyembuhan penyakit maupun untuk memulihkan kesehatan tubuh (Haniffa et al., 2014; Tawali dkk., 2012; Mustafa et al., 2012; Paul et al., 2013). Pengolahan ikan ini ke arah industri makanan kesehatan telah menjadi peluang pemanfaatan ikan dalam skala yang lebih besar, tetapi aktivitas ini juga membuka peluang bagi timbulnya masalah pada meningkatnya produk samping hasil pengolahan, termasuk diantaranya tulang.

Tulang ikan merupakan bahan baku yang tersusun atas komponen organik maupun non-organik (mineral) penting, dan merupakan produk sampingan utama dari perikanan dan industri akuakultur. Limbah setelah filleting dapat mencapai sekitar $75 \%$ dari total berat ikan dan terdapat sekitar 30\% dari limbah tersebut berupa tulang dan kulit (Songchotikunpan et al., 2008). Mohtar et al. (2011) mengemukakan berdasarkan informasi MSC (2009) bahwa jumlah produk samping ikan memberikan kontribusi hampir 36\% dari total berat ikan. Lebih lanjut Mohtar et al. (2011) juga menyebutkan bahwa limbah pengolahan ikan saat ini masih kurang dimanfaatkan dalam industri perikanan, dan gelatin ikan akan menjadi cara yang baik untuk meningkatkan nilai tambah produk sampingan ini. Selain memecahkan masalah pembuangan limbah, Songchotikunpan et al. (2008) menyebutkan bahwa pemanfaatan produk samping perikanan akan menciptakan produk bernilai tambah. 
Penelitian ini bertujuan mengkarakterisasi komponen organik dan anorganik yang terkandung dalam tulang ikan gabus, sebagai bahan informasi bagi pemanfaatan lebih lanjut.

\section{METODOLOGI PENELITIAN}

\section{Waktu dan Tempat}

Penelitian berlangsung sejak April sampai November 2016. Ikan gabus diperoleh dari Bendungan Bili Bili, Gowa. Preparasi sampel dilaksanakan di beberapa laboratorium, antara lain Laboratorium Pengembangan Hasil Pertanian, Fakultas Pertanian (Preparasi tulang ikan untuk uji karakteristik, Laboratorium Bioteknologi Terpadu Fakultas Peternakan (liofilisasi sampel), Laboratorium Kimia Nutrisi Makanan Ternak Fakultas Peternakan (analisis proksimat), Laboratorium Fisika FMIPA-UNM (SEM-EDS), Laboratorium Terpadu Teknologi Hasil Ternak Fakultas Peternakan IPB (analisis Hidroksiprolin), dan PT. Saraswanti Indo Genetech, Bogor (analisis asam amino).

\section{Materi Penelitian}

Bahan utama yang digunakan dalam penelitian ini adalah tulang yang berasal dari ikan gabus (Channa Striata) dengan ukuran 300-400 g/ekor, 600-700 g/ekor dan 900-1.000 g/ekor. Beberapa bahan kimia untuk analisis berupa $\mathrm{H}_{2} \mathrm{SO}_{4}, \mathrm{H}_{3} \mathrm{BO}_{3}, \mathrm{NaOH} 30 \%, \mathrm{HCl} 0,02 \mathrm{~N}$, chloroform, dan hidroksiprolin standard.

\section{Peralatan Penelitian}

Peralatan yang digunakan antara lain alat untuk proses preparasi dan alat untuk analisis uji sampel. Alat proses antara lain pisau, tang dan peralatan penunjang lain untuk preparasi tulang. waterbath, freezer, freeze dryer, (ALPHA 1-2 LD plus), grinder, timbangan analitik, plastik kemasan dan botol kemasan. Peralatan untuk analisis proksimat antara lain neraca analitik, cawan porselen, oven, tanur, desikator, labu Kjeldhal, destilator, penangas listrik, lemari asam, buret, labu Erlenmeyer, labu ukur. High-Performance Liquid Chromatography (HPLC, 1200 Infinity Series by Agilent Technologies) (kadar hidroksiprolin) dan UPLC (Ultra Performance Liquid Chromatograph, ACQUITY UPLCH Class) (asam amino) dan Scanning Electron Microscopis-Energy Dispersive Spectroscopy (SEM-EDS, Tescan Vega3SB). 


\section{Metode Penelitian}

Penelitian ini bersifat percobaan di laboratorium dengan menggunakan metode Rancangan Percobaan. Penelitian terdiri atas prersiapan bahan baku, preparasi sampel dan analisis karakteristik fisiko-kimia sampel.

\section{Persiapan bahan baku}

Ikan gabus segar ditimbang untuk menetapkan kelompok perlakuan. Perbedaan bobot badan diduga dapat mewakili usia ikan gabus, semakin besar bobot badan maka usia ikan semakin tua. Ikan dibersihkan dengan mengeluarkan bagian sisik, kepala, sirip dan viseranya. Ikan di-fillet untuk mendapatkan bagian tulang. Tulang dibersihkan dan dikemas dalam kantung plastik polietilen tertutup untuk dianalisis lebih lanjut.

2. Preparasi tulang ikan gabus

Preparasi tulang merujuk pada Wulandari dkk. (2013) dan Kittiphattanabawon et al. (2005). Sebelum digunakan, terlebih dahulu lemak dan daging yang masih menempel pada tulang dihilangkan dengan cara degreasing, yaitu merendamnya dalam air panas suhu 60$70{ }^{\circ} \mathrm{C}$ sekitar 30 menit. Analisis proksimat tulang menggunakan tulang hasil degreasing. Tulang untuk analisis kadar asam amino, dan mikrostruktur jaringan dan komposisi mineral terlebih dahulu diperkecil ukurannya, kemudian diliofilisasi (sekitar 24 jam). Tulang yang telah kering, digiling membentuk tepung menggunakan alat penggiling dan disimpan pada suhu di bawah $4{ }^{\circ} \mathrm{C}$ hingga siap dianalisis.

\section{Prosedur Penelitian}

\subsection{Analisis Proksimat (AOAC, 1995)}

Komposisi terdekat ditentukan menggunakan prosedur AOAC (1995). Kadar air ditentukan dengan menggunakan metode gravimetri. Metode Kjeldahl digunakan untuk penentuan kadar protein kasar (faktor konversi 6,25 $\times \mathrm{N}$ ). Konten lipid ditentukan dengan menggunakan metode Soxhlet. Kandungan abu ditentukan oleh insinerasi selama 16 jam pada $550^{\circ} \mathrm{C}$.

\subsection{Analisis Asam Amino}

Kandungan asam amino ditentukan menurut Nollet (1996). Asam amino dianalisis dengan menggunakan Kromatografi Cair Kinerja Ultra (UPLC, ACQUITY UPLC-H Class). Sampel $(0,1 \mathrm{~g})$ dihidrolisis dalam $5 \mathrm{~mL} 6 \mathrm{~N} \mathrm{HCl}$ dan dipanaskan pada $100{ }^{\circ} \mathrm{C}$ selama 22 jam. Suatu larutan yang mengandung $500 \mu \mathrm{L}$ filtrat, $40 \mu \mathrm{m}$ AABQ, dan $460 \mu \mathrm{L}$ air suling disiapkan. Larutan $(10 \mu \mathrm{L})$ ditambahkan dengan AccQ-Fluor Borat dan $20 \mu \mathrm{L}$ reagent FlourA diinkubasi selama 10 menit pada $550^{\circ} \mathrm{C}$, kemudian disuntikkan dalam sistem UPLC.

\subsection{Analisis Hydroxyproline}


Kandungan kolagen yang diperkirakan ditentukan berdasarkan nilai hidroksiprolin asam amino. Kadar hidroksiprolin diukur menggunakan High-Performance Liquid Chromatography (HPLC, 1200 Infinity Series oleh Agilent Technologies), berdasarkan Henderson Jr. dan Brooks (2010) metode. Sebelum injeksi HPLC, sampel dihidrolisis dalam $1 \mathrm{~mL} 6 \mathrm{~N} \mathrm{HCl}$ dan dipanaskan pada $110^{\circ} \mathrm{C}$ selama 24 jam. Larutan standar menggunakan L-hydroxyproline (Sigma, USA) digunakan. Perkiraan kadar kolagen yang terkandung dalam kulit ikan snakehead dihitung berdasarkan nilai hidroksiprolin dikalikan dengan faktor 8,0 (Muralidharan et al, 2013).

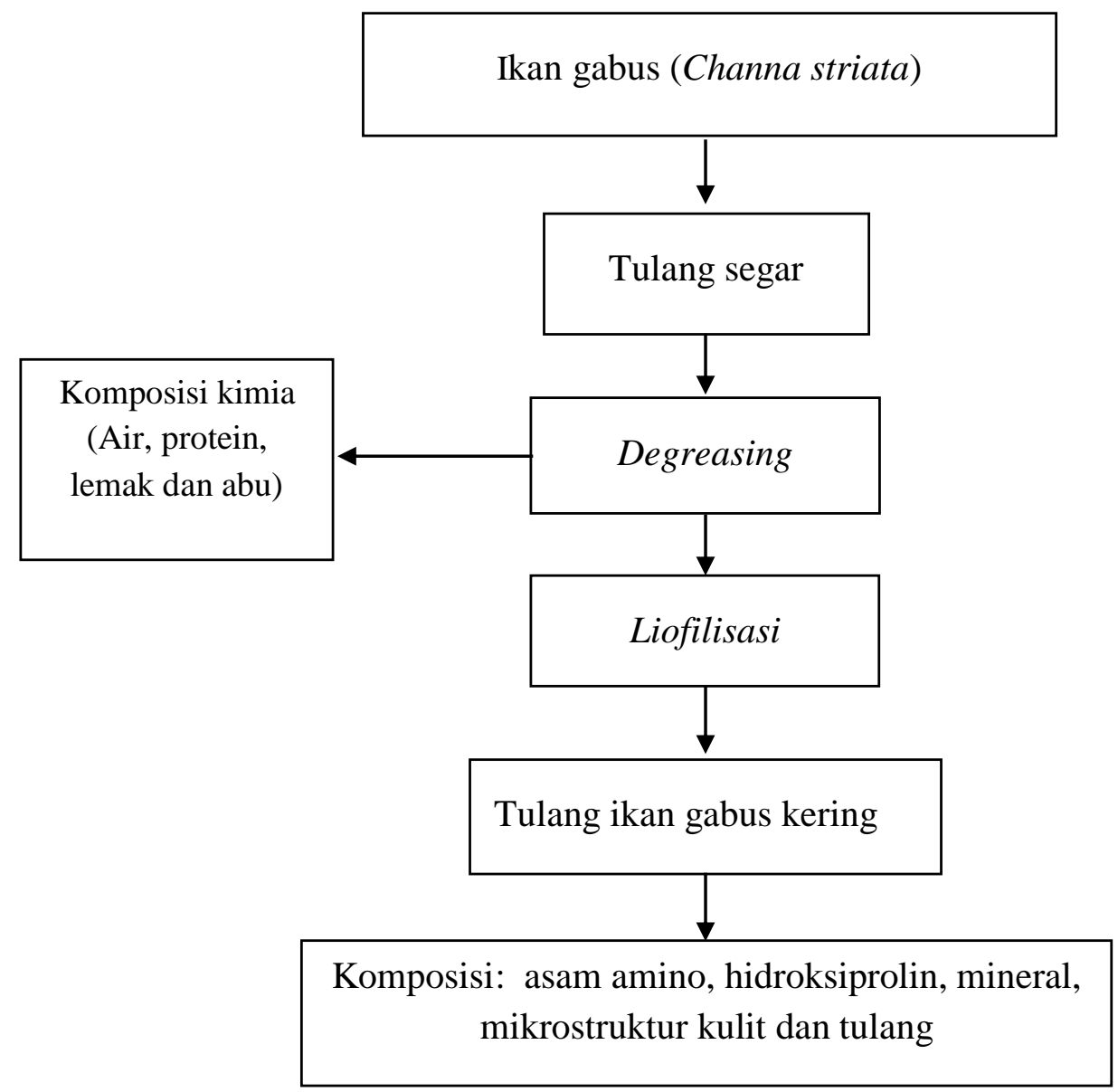

Gambar 1. Diagram alir penelitian

\section{Gambar 1. Alur penelitian}

\subsection{Analisis Scanning Electron Microscopy (SEM)}

Mikro kulit ikan snakehead diamati dengan Scanning Electron Microscopy (SEM, Tescan Vega3SB) dengan perbesaran 500 kali, mengacu pada prosedur Ramadhan dkk. (2014). Sampel yang siap ditempelkan ke pemegang dilapisi dengan pita karbon. Sampel kemudian dilapisi dengan menggunakan emas paladium untuk mencegah kontak langsung dengan sampel elektron. Sampel dilapisi ditempatkan di ruang SEM. Ruang SEM disedot 
dengan menyalakan pompa otomatis pada perangkat lunak VEGA. Proses vakum harus dilakukan dengan sempurna. Di ruang, akan ada tembakan elektron ke arah sampel sehingga ada rekaman pada monitor dan pemotretan berikutnya.

\subsection{Analisis Energy Dispersive Spectroscopy (EDS)}

Spektroskopi Dispersif Energi (EDS, Tescan Vega3SB) adalah perangkat yang sama dengan SEM. EDS digunakan untuk menentukan komponen mineral dari sampel (Yin et al., 2016). Komposisi permukaan mineral yang terkandung dalam sampel menggunakan peralatan emisi SEM dengan detektor untuk spektroskopi Energy Dispersive X-ray. Pengukuran dilakukan pada tegangan akselerasi berkas elektron $20 \mathrm{kV}$. Untuk mengetahui komponen mineral dari sampel, sampel dilapisi dengan emas Palladium untuk membuatnya konduktif.

\section{Analisis statistik}

Data eksperimen dievaluasi menggunakan analisis varians (ANOVA) berdasarkan desain acak lengkap (RAL). Signifikansi varians diverifikasi menggunakan Uji Duncan. Data dianalisis menggunakan perangkat lunak SPSS. Data lainnya dianalisis secara deskriptif.

\section{HASIL DAN PEMBAHASAN}

Kadar Proksimat dan Kolagen Tulang Ikan Gabus

Analisis proksimat berfungsi sebagai metode untuk mengidentifikasi komposisi kimia yang dijadikan dasar dalam memahami karakteristik fisiko-kimia suatu bahan pangan. Hasil analisis sidik ragam menunjukkan bahwa bobot badan, berpengaruh nyata $(\mathrm{P}<0,05)$ terhadap kadar air. Kadar proksimat tulang ikan gabus meliputi kadar air, protein, lemak, dan abu, serta kadar kolagen tersaji pada Tabel 1.

Tabel 1. Kadar proksimat dan kolagen tulang ikan gabus pada bobot badan berbeda

\begin{tabular}{llllll}
\hline $\begin{array}{l}\text { Bobot badan } \\
(\mathrm{g})\end{array}$ & Air & Protein & Lemak & Abu & Kolagen \\
& & & & \\
& & & & \\
& & & & \\
\hline $300-400$ & $46,69 \pm 1,53^{\mathrm{a}}$ & $15,01 \pm 0,81^{\mathrm{a}}$ & $2.54 \pm 0,02^{\mathrm{a}}$ & $29,82 \pm 0,63^{\mathrm{a}}$ & $9,88 \pm 0,49^{\mathrm{a}}$ \\
$600-700$ & $43,16 \pm 0,09^{\mathrm{b}}$ & $16,09 \pm 0,62^{\mathrm{a}}$ & $4,05 \pm 0,44^{\mathrm{b}}$ & $31,88 \pm 0,46^{\mathrm{b}}$ & $8,85 \pm 0,84^{\mathrm{b}}$
\end{tabular}


$900-1.000$

Superskrip yang berbeda pada baris yang sama menunjukkan perbedaan nyata $(\mathrm{P}<0,05), \mathrm{n}=3$

Air merupakan komponen utama penyusun tubuh ikan (Njinkoue et al., 2016) yang terikat secara fisik dan kimia. Terdapat indikasi semakin bertambah bobot badan maka kadar air ikan gabus cenderung menurun, sebagaimana pada Tabel 1. Adanya penurunan ini mungkin saja dipengaruhi oleh komposisi kimia lain yang juga cenderung mengalami perubahan, Sebagai penyusun utama, air sangat dibutuhkan terutama pada proses metabolisme, transportasi, dan berbagai aktivitas vital dan untuk mempertahankan sistem keseimbangan tubuh ikan. Proses pertumbuhan menyebabkan perubahan persentase kadar air. Pertambahan bobot badan mengakibatkan kadar air cenderung menurun. Hal ini menurut Breck (2014) disinyalir oleh aktivitas biokimia tubuh, dimana peningkatan massa tubuh bertanggung jawab atas penurunan kadar air dan adanya kecenderungan peningkatan pada kandungan protein. Saat bertumbuh, pada banyak spesies ikan kadar lemak, protein dan energi meningkat yang disertai oleh penurunan kadar air (Jonsson dan Jonsson, 1998). Kadar air yang tinggi ini menjadi salah satu faktor perlunya penanganan tulang ikan untuk mengurangi timbulnya masalah bagi pencemaran lingkungan, karena terjadinya dekomposisi komponen-komponen tulang baik oleh enzim maupun mikroorganisme.

Protein merupakan komponen tubuh utama setelah air, dan hasil analisis sidik ragam memperlihatkan tidak ada pengaruh nyata $(\mathrm{P}>0,05)$ perbedaan bobot badan terhadap kadar protein pada tulang. Meskipun telah menjadi kesepakatan sejumlah peneliti (Naeem et al., 2016) bahwa ada korelasi positif pertambahan bobot dengan peningkatan kadar protein tubuh, tetapi pertambahan kadar protein ikan gabus dalam penelitian ini tampaknya cukup lambat sehingga tidak menunjukkan perbedaan nyata antara bobot yang berbeda $(\mathrm{P}>0,05)$, sebagaimana halnya pada kulit ikan gabus (Rosmawati et al., 2018). Lambatnya peningkatan kadar protein ikan gabus seiring meningkatnya bobot badan mungkin ada kaitannya dengan respon tubuh mensintesis protein, atau ada hubungannya dengan ketersediaan pakan di lingkungan tempat ikan gabus ditangkap. Kadar protein tulang ikan gabus sebagaimana pada Tabel 1 cenderung sedikit lebih tinggi dari yang dilaporkan oleh Hemung (2013) pada tepung tulang ikan tilapia yaitu $14,81 \pm 0,33 \%$, demikian halnya protein tulang ikan leather jacket (Odonus niger) yang dilaporkan oleh Muralidharan et al. (2013) yaitu 11,86 $\pm 0,35 \%$. Persentase protein tulang yang lebih rendah mungkin dapat dikaitkan dengan proporsi mineral tulang yang relatif tinggi. 
Terdapat kecenderungan pertambahan bobot badan ikan gabus berkorelasi positif dengan peningkatan kadar lemak pada tulang. Hasil analisis sidik ragam menunjukkan ada pengaruh pertambahan bobot badan $(\mathrm{P}<0,05)$ terhadap kadar lemak pada tulang ikan. Semakin bertambah bobot badan cenderung mengakibatkan terjadinya peningkatan terhadap kadar lemak pada tulang ikan gabus, sebagaimana Abdel-Tawwab et al. (2015), tetapi kadarnya dapat bervariasi di antara jenis ikan berbeda (Henderson dan Tocher, 1987; Yeannes dan Almandos, 2003). Beberapa penelitian lain menunjukkan variasi kadar lemak pada ikan dari species berbeda antara lain Ama-Abasi dan Ogar (2012) pada ikan gabus Nigeria (Parachanna obscura) pada bobot 130-195 g yaitu 17,10 \pm 0,01 sampai 17,40 \pm $0,02 \mathrm{mg} / 100 \mathrm{~g}$, dan Zuraini et al. (2006) pada Channa striata yaitu 5,7 $\pm 1,9 \%$. Adanya perbedaan ini dapat disebabkan oleh faktor fisiologis seperti jenis kelamin dan reproduksi, musim dan kondisi lingkungan dimana ikan tersebut ditangkap (Shim et al., 2017; Suseno et al., 2014; Boran dan Karaçam, 2011; Puwastien et al., 1999). Patrick Saoud et al. (2008) mengemukakan bahwa persentase lemak dalam jaringan menurun saat pemijahan, yang menurut Boran dan Karaçam (2011) menjadi salah satu faktor menyebabkan komposisi kimia ikan bervariasi.

Kadar abu tulang ikan gabus cenderung meningkat seiring dengan pertambahan bobot badan. Sebagaimana hasil analisis sidik ragam menunjukkan bahwa bobot badan berpengaruh nyata $(\mathrm{P}<0,05)$ terhadap kadar abu tulang ikan gabus (Tabel 1). Pertambahan bobot badan menyebabkan proses mineralisasi cenderung meningkat. Salam dan Davies (1994) yang melakukan pengamatan pada ikan pike (Esox lucius L.) menemukan peningkatan kadar abu yang cukup konstan, bahkan korelasinya dengan ukuran tubuh adalah negatif sebagaimana kadar air. Hal yang sama dijumpai oleh Naeem et al. (2016) bahwa ada hubungan negatif antara peningkatan bobot tubuh dengan kadar air dan kadar abu. Tetapi temuan ini tidak dapat dianggap telah mewakili secara tepat kadar abu pada tulang ikan gabus pada bobot berbeda, karena adanya sejumlah faktor yang dapat mempengaruhi, karena itu perlu validasi dengan melakukan pengamatan berulang pada rentang bobot yang lebih beragam dan pada kondisi fisiologis berbeda. Mungkin juga, ketersediaan mineral di habitat akan memberi andil terhadap persentase kadar abu pada tulang ikan, sebagaimana bahwa kadar abu adalah representasi dari kandungan mineral tubuh yang terakumulasi di dalam tubuh ikan. Kadar abu tulang ikan gabus adalah sekitar 31,25\% dari total bahan penyusun tulang, yang lebih rendah dari kadar abu tulang ikan Pseudotolithus elongatus dan Pseudotolithus typus yaitu berturut-turut 39,30 \pm 0,44\% dan 45,54 \pm 0,35\% (Njinkoue et al., 2016). aktivitas tubuh yang tinggi menurut Toppe et al. (2007) seperti berenang mengindikasikan adanya kebutuhan elastisitas tulang yang lebih baik untuk mendukung 
aktivitas fisik yang tinggi, yang berimplikasi pada rendahnya kadar abu, sebagaimana yang dijumpai pada beberapa jenis ikan.

Data yang tersaji pada Tabel 1 menunjukkan ada pengaruh bobot badan $(\mathrm{P}<0,05)$ terhadap kandungan kolagen tulang ikan gabus. Ada kecenderungan semakin tinggi bobot badan kadar kolagen relatif menurun. Keadaan ini dapat dikaitkan dengan kebutuhan tubuh akan asam amino hidroksiprolin yang diduga cenderung menurun seiring meningkatnya bobot badan. Hidroksiprolin adalah asam amino hasil sintesis dari prolin dengan bantuan enzim prolyl-hydroksilase sebagai katalis, dan sebagai ko-faktornya adalah zat besi, asam askorbat dan oksigen (Albaugh et al., 2017; Zhang et al., 2015). Asam amino ini menurut Li et al. (2009) dianggap merupakan asam amino esensial kondisional (Conditionally Essential Amino Acid, CEAA), karena asam amino ini menurutnya harus ada dalam diet akibat tingkat pemanfaatannya lebih besar dari yang mampu disentesis oleh tubuh. Rendahnya kadar kolagen pada tulang ikan gabus mungkin ada hubungannya dengan asupan asam amino hidroksiprolin maupun prolin di habitatnya. Ini telah dibuktikan oleh Aksnes et al. (2008) dan Blanco et al. (2017) terhadap suplementasi hidroksiprolin, dan mengindikasikan adanya peningkatan pada kadar hidroksiprolin jaringan dan kadar kolagen yang terkandung dalam otot ikan. Hidroksiprolin adalah salah satu asam amino penting dan unik, dan bersama prolin merupakan penyusun utama protein kolagen tubuh yang berfungsi mempertahankan struktur dan fungsi sel (Wu et al. 2011). Kadar kolagen ikan gabus lebih rendah dari yang telah dilaporkan oleh Blanko et al. (2017) pada beberapa jenis ikan laut. Adanya perbedaan kadar kolagen ini dapat dikaitkan dengan sturktur/tipe kolagen yang berbeda, tergantung pada species, jenis organ maupun lingkungan hidup ikan (Blanko et al., 2017; Duan et al., 2009), dan faktor teknis-analisis serta komposisi asam iminonya (Liu et al., 2015). Kolagen merupakan protein khas yang hanya terdapat pada jaringan ikat dengan untaian asam amino yang dicirikan oleh adanya asam amino glisin, prolin dan hidroksiprolin, dan untuk memastikan adanya kolagen maka menurut Albaugh et al. (2017) uji asam amino hidroksiprolin adalah cara yang tepat untuk menandainya.

\section{Asam Amino}

Asam amino adalah representasi dari kandungan protein. Ikan gabus merupakan sumber asam amino potensial dengan manfaatnya dalam pengobatan dan penyembuhan luka. Profil asam amino tulang ikan pada bobot berbeda tersaji pada Tabel 2.

Hasil penelitian menunjukkan bahwa kulit dan tulang ikan gabus termasuk bagian dari sisa hasil pengolahan yang mengandung asam-asam amino dengan kadar yang relatif lebih rendah dibanding pada kulit (Rosmawati et al., 2018). Tulang ikan gabus mengandung 
semua asam amino esensial (histidin, arginin, treonin, lisin, metionin, valin, isoleusin, leusin, phenilalanin dan triptofan), beberapa asam amino non esensial (serin, asam aspartate, asam glutamate, alanine, dan tirosin) dan asam amino esensial secara kondisional (glisin, prolin dan sistin). Glisin, prolin dan sistin (termasuk hidroksiprolin) menurut Li et al. (2009), Li dan Wu (2017) sekarang ini telah dianggap sebagai asam amino esensial bagi sejumlah hewan termasuk di antaranya ikan, sebagaimana pembuktian yang telah dilakukan oleh Aksnes et al. (2008), Liu et al. (2014), Xie et al. (2016), Zhang et al. (2015). Meskipun kadar asam amino pada kulit ikan gabus lebih tinggi (Rosmawati et al., 2018) dibandingkan tulang, tetapi antara asam-asam amino yang sama relatif berada pada kisaran yang tidak berbeda jauh

Tabel 2. Kandungan asam amino kulit dan tulang ikan gabus pada bobot badan berbeda

\begin{tabular}{lrrr}
\hline Asam amino & $300-400 \mathrm{~g}$ & $600-700 \mathrm{~g}$ & $900-1.000 \mathrm{~g}$ \\
\hline L-Histidin & 1,54 & 1,48 & 1,53 \\
L-Serin & 4,18 & 4,10 & 4,16 \\
L-Arginin & 7,46 & 7,24 & 7,78 \\
Glisin & 22,48 & 21,33 & 23,34 \\
L-Asam aspartat & 6,21 & 6,76 & 5,71 \\
L-Asam glutamat & 12,03 & 12,84 & 11,50 \\
L-Threonin & 3,60 & 3,54 & 3,66 \\
L-Alanin & 9,67 & 9,88 & 9,57 \\
L-Prolin & 11,84 & 11,45 & 12,12 \\
L-Sistin & 0,07 & 0,04 & 0,06 \\
L-Lisin & 5,51 & 5,92 & 5,22 \\
L-Tirosin & 1,43 & 1,43 & 1,43 \\
L-Metionin & 1,45 & 1,41 & 1,57 \\
L-Valin & 3,25 & 3,22 & 3,19 \\
L-Isoleuin & 2,18 & 2,21 & 2,14 \\
L-Leusin & 3,88 & 3,92 & 3,84 \\
L-Phenilalanin & 3,05 & 3,10 & 3,05 \\
Triptophan & 0,16 & 0,13 & 0,12 \\
\hline & & & \\
\hline
\end{tabular}

Asam amino memiliki fungsi vital dalam proses biokimia (Mat Jais et al., 1994). Mereka juga merupakan prekursor penting untuk sintesis berbagai molekul serta regulasi berbagai fungsi metabolik, seperti kesehatan, pertumbuhan, perkembangan, reproduksi, dan 
homeostasis (Haniffa et al., 2014; Zuraini et al., 2006). Tulang ikan gabus mengandung asam amino yang hampir lengkap sebagaimana yang dijumpai pada daging ikan gabus (Zuraini et al., 2006; Tan dan Azhar, 2014; Mat Jais et al., 1994; Gam et al., 2005), meskipun masing-masing jaringan tersebut memiliki mekanisme dan fungsi yang berbeda, karena terkait dengan komposisi masing-masing asam aminonya.

\section{Mikrostruktur Tulang Ikan Gabus}

Pengamatan mikrostruktur tulang ikan gabus menggunakan scanning elektron mikroscopis (SEM) disajikan pada Gambar 2. Profil mikrostruktur tulang ikan gabus tidak memperlihatkan adanya serabut maupun fibril sebagaimana pada serat daging maupun kulit. Hal ini karena tulang tersusun dari bahan anorganik yang relatif padat, sehingga bagianbagian tulang berdasarkan SEM masih sulit diidentifikasi.

Kolagen adalah salah satu protein utama jaringan ikat, terdiri dari fibril dan tersusun dalam rangkaian heliks yang membentuk struktur jaringan yang kuat dan elastis. Pada tulang, protein yang didominasi oleh kolagen merupakan komposit penyusun bersama dengan bahan anorganik (hidroksiapatite) bersama protein non-kolagen (Olszta et al., 2007) lemak dan air (Szpak, 2011). Kolagen bersama dengan mineral menyusun matriks tulang yang memberi kekuatan dan elastisitas pada tulang sehingga tulang tidak menjadi kaku. Tidak ada perbedaan yang mencolok antara mikrostruktur sampel pada bobot badan berbeda baik pada kulit maupun tulang. Namun, Suárez et al. (2015) menyarankan bahwa umur ikan menjadi faktor yang perlu dipertimbangkan; termasuk kegiatan budidaya menjadi penting dengan pertimbangan diet yang tepat dalam rangka mengarahkan potensi dan tujuan pemanfaatan.

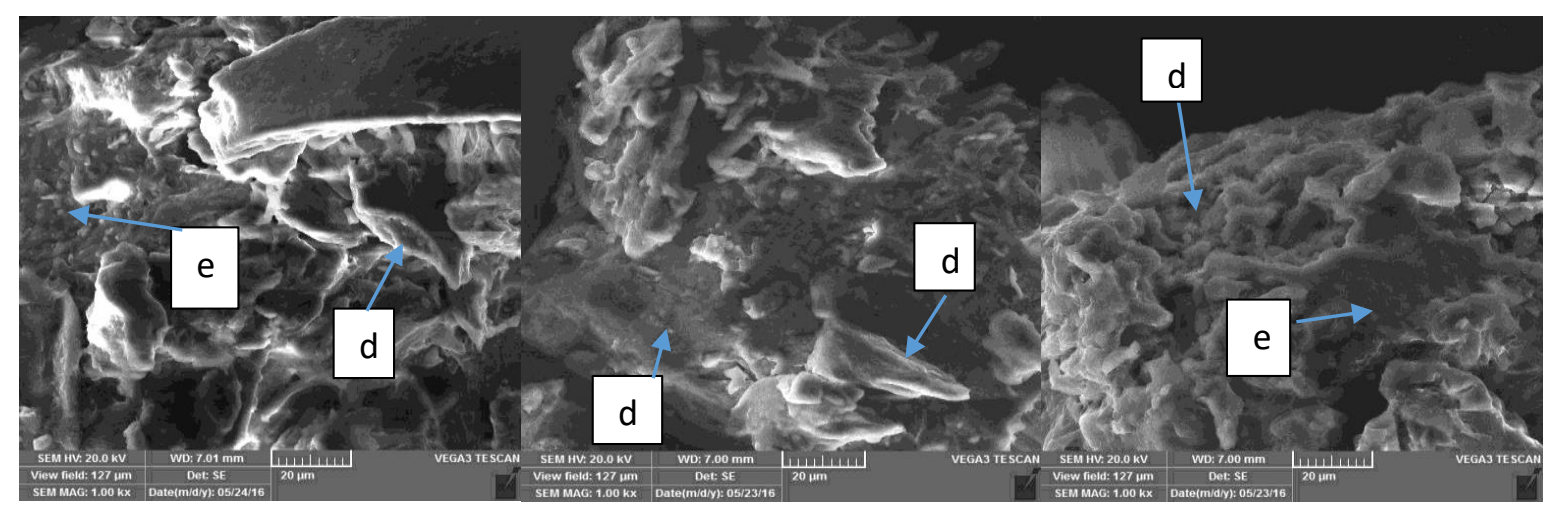


Gambar 2. Mikrostruktur tulang ikan gabus. Sampel tulang ukuran 300-400 g (a); 600700 g (b) 900-1.000 g (c); komposit organik-anorganik penyusun tulang (d); kristal hidroksiapatit yang terinvestasi dalam bundle kolagen (e).

\section{Kadar Mineral}

Kadar abu dari bahan anorganik adalah akumulasi mineral yang terkandung dalam bahan baku. Secara umum, SEM-EDS (Scanning Electron Microscopis-Energy Dispersive Spectroscopy) dapat mendeteksi adanya sejumlah mineral yang terkandung pada sampel, termasuk tulang, tetapi hanya mampu menjangkau pada bagian permukaan saja. Kelemahan alat ini mengakibatkan sulitnya memprediksi kadar mineral sampel berdasarkan satuan bobot sampel. Distribusi mineral pada permukaan sampel yang diamati tidak seragam, baik secara jenis maupun kuantitas, dikarenakan sampel uji yang dianalisis dalam bentuk tepung dengan tingkat homogenitas yang relatif tidak merata. Tetapi setidaknya alat ini dapat membantu memprediksi kandungan mineral dari tulang ikan gabus yang diamati. Berdasarkan data perkiraan mineral pada Tabel 3 di atas menunjukkan kandungan mineral tertinggi yang terdapat pada tulang yaitu kalsium kemudian fosfor, adapun mineral lain berada dalam kisaran yang lebih rendah.

Tabel 3. Komposisi mineral yang terkandung dalam kulit dan tulang ikan

\begin{tabular}{lrrr}
\hline Mineral & $300-400 \mathrm{~g}$ & $600-700 \mathrm{~g}$ & $900-1.000 \mathrm{~g}$ \\
\hline Kalsium & 22,00 & 18,58 & 21,74 \\
Fosfor & 12,95 & 12,44 & 12,82 \\
Magnesium & 1,34 & 1,76 & 1,29 \\
Natrium & 2,59 & 2,87 & 2,33 \\
Kalium & 0,41 & 0,51 & 0,63 \\
Sulfur & 0,44 & 0,61 & 0,53 \\
Klorin & 0,05 & 0,32 & $\mathrm{td}$ \\
Besi & $\mathrm{td}$ & $\mathrm{td}$ & 0,18 \\
Mangan & $\mathrm{td}$ & $\mathrm{td}$ & 0,13 \\
Aluminium & 0,41 & 0,69 & 0,35 \\
Chromium & $\mathrm{td}$ & $\mathrm{td}$ & 0,09 \\
Silikon & 0,21 & 0,44 & 0,12 \\
Titanium & $\mathrm{td}$ & 0,18 & $\mathrm{td}$ \\
\hline
\end{tabular}

*td: tidak terdeteksi 
Sejumlah mineral sebagaimana pada Tabel 3 adalah mineral penting yang dibutuhkan oleh tubuh ikan, meskipun beberapa di antaranya seperti titanium termasuk mineral yang terinduksi masuk dalam tubuh ikan gabus sehingga dijumpai ada dalam sampel uji. Mengetahui kandungan mineral kulit dan tulang akan bermanfaat terutama sebagai informasi awal, apakah bahan baku ini aman dari paparan sejumlah logam berat yang dapat terakumulasi dalam produk turunan tulang yang akan dihasilkan. Rivas et al. (2014) menyatakan bahwa mineral memainkan peran penting dalam proses metabolisme, dan bertanggung jawab untuk mengendalikan fungsi biologis tubuh. Sejumlah mineral menurut Atanasoff et al. (2013) tidak terpengaruh oleh bobot ikan namun dapat dikaitkan dengan faktor-faktor seperti musim, usia, kondisi reproduksi, sumber pakan, dan habitat ikan.

\section{KESIMPULAN}

Kadar proksimat dan kolagen tulang ikan gabus cenderung dipengaruhi oleh pertambahan bobot badan meskipun antara bobot 600-700 g/ekor sampai 900-1.000 g/ ekor menunjukkan adanya kesamaan pada komposisi kimianya. Berdasarkan profil asam amino menunjukkan kadar asam amino glisin dan prolin adalah tertinggi pada ketiga kisaran bobot badan, yang mengindikasikan bahwa tulang berpotensi dijadikan sebagai bahan baku sumber kolagen. Kandungan mineral terutama kalsium dan fosfor yang relatif tinggi berpotensi menjadikan tulang ikan gabus sebagai sumber mineral baik untuk pakan ternak/ikan, maupun fortifikasi produk berbasis pangan fungsional.

\section{UCAPAN TERIMAKASIH}

Penelitian ini didukung oleh Kemenristek Dikti dan Rektor Universitas Hasanuddin melalui Hibah Riset Unggulan Universitas Hasanuddin (RUNAS) No. 41740/UN4.3.2/LK.23/2016

\section{DAFTAR PUSTAKA}

Assosiation of Official Analytical Chemists (AOAC). 1995. Official Methods of Analysis (16 ${ }^{\text {th }}$ ed.). Washington, DC.

Abdel-Tawwab, M., Ahmed E. Hagras, A. E., Heba Allah M. Elbaghdady, H. A. M., and Monier, M. N. 2015. Effects of dissolved oxygen and fish size on Nile tilapia, Oreochromis niloticus (L.): growth performance, wholebody composition, and innate immunity. Aquacultur International. Vol. 23(5): 1261-1274. https://doi.org/10.1007/s10499-015-9882-y 
Ama-Abasi, D. and Ogar, A. 2012. Proximate analysis of snakehead fish, Parachanna obscura (Gunther, 1861) of the Cross Rivers, Nigeria. Journal of Fisheries and Aquatic Science. 1-4. doi: 10.3923/jfas.2012.

Albaugh, V. L., Mukherjee, K., and Barbul, A. 2017. Proline Precursors and Collagen Synthesis: Biochemical Challenges of Nutrient.Supplementation and Wound Healing. The Journal of Nutrition. 1-7. https://doi.org/10.3945/jn.117.256404

Aksnes A, Mundheim H, Toppe J, and Albrektsen S. (2008) The effect of dietary hydroxyproline supplementation on salmon (Salmo salar L.) fed high plant protein diets. $\quad$ Aquaculture 275 (1-4): https://doi.org/10.1016/j.aquaculture.2007.12.031

Atanasoff, A., Nikolov, G., Staykov, Y., Zhelyazkov, G., \& Sirakov, I., (2013). Proximate and mineral analysis of Atlantic salmon (Salmo Salar) cultivated in Bulgaria. Biotechnol. Anim. Husb. 29, 571-579. doi:10.2298/BAH1303571A

Blanco, M., José Antonio Vázquez, J.A, Pérez-Martín, R.I., and Carmen G. Sotelo, C.G. Hydrolysates of Fish Skin Collagen: An Opportunity for Valorizing Fish Industry Byproducts. Marine Drugs. 131:1-15. doi:10.3390/md15050131

Boran, G., and Karaçam, H. 2011. Seasonal changes in the proximate composition of some fish species from the Black Sea. Turkish Journal of Fisheries and Aquatic Sciences, 11, 01-05. doi:10.4194/trjfas.2011.0101

Boran, G. and J. M. Regenstein. 2010. Chapter 5 - Fish Gelatin. Advances in Food and Nutrition Research, 60. pp. 119-143.Breck, J. 2014. Body composition in fishes: Body size matters. Aquaculture, 433, 40-49. http://dx.doi.org/10.1016/j.aquaculture.2014.05.049

Duan, R., Junjie Zhang, J., Du, X., Yao, X., and Konno, K. 2009. Properties of collagen from skin, scale and bone of carp (Cyprinus carpio). Food Chemistry, 112 (2009) 702-706. https://doi.org/10.1016/j.foodchem.2008.06.020

Gam, L.H., Leow, C.Y., \& Baie, S. 2005. Amino acid composition of snakehead fish (Channa striatus) of various size obtained at different time of the year. Malaysian Journal of Pharmaceutical Science, 3(2), 19-30.

Haniffa, M. A. K., P. A. J. Sheela, K. Kavitha and A. M. M. Jais. 2014. Salutary value of haruan, the striped snakehead Channa striata - A Review. Asian Pacific Journal of Tropical Biomedicine. Vol. $4 \quad$ (Suppl 1). Pp. $\quad$ S8-S15. https://doi.org/10.12980/APJTB.4.2014C1015 
Hemung, B. O. 2013. Properties of Tilapia Bone Powder and Its Calcium Bioavailability Based on Transglutaminase Assay. International Journal of Bioscience, Biochemistry and Bioinformatics, 3(4): 306-309. DOI: 10.7763/IJBBB.2013.V3.219

Henderson Jr., J.W. and A. Brooks. 2010. Improved Amino acid methods using Agilent ZORBAX Eclipse plus C18 colums for a variety of Agilent LC instrumentation and separation goals. Agilent Pub \#5990-4547EN.

Henderson R. J. and Tocher, D. R. 1987. The lipid composition and biochemistry of fresh water fish. Progress in Lipid Research, 26(4): 281-347. https://doi.org/10.1016/0163-7827(87)90002-6

Jonsson, N and Jonsson B. 1998. Body composition and energy allocation in life-history stages of brown trout. Journal of Fish Biology, 53(6), 1306-1316. https://doi.org/10.1111/j.1095-8649.1998.tb00250.x

Kittiphattanabawon, P., Benjakul, S., Visessanguan, W., Nagai, T., and Tanaka, M. 2005. Characterisation of acid-soluble collagen from skin and bone of bigeye snapper (Priacanthus tayenus). Food Chemistry, 89(3): 363-372. https://doi.org/10.1016/j.foodchem.2004.02.042

Li, P., Mai K.S., Trushenski J. and Wu, G. 2009. New developments in fish amino acid nutrition: towards functional and environmentally oriented aquafeeds. Amino Acids 37(1):43-53. https://doi.org/10.1007/s00726-008-0171-1

Li, P. and Wu, G. 2017. Roles of dietary glycine, proline, and hydroxyproline in collagen synthesis and animal growth. Amino Acids. 1-10. https://doi.org/10.1007/s00726017-2490-6

Liu Y, He G, Wang Q, Mai K, Xu W, Zhou H (2014) Hydroxyproline supplementation on the performances of high plant protein source based diets in turbot (Scophthalmus $\begin{array}{lll}\text { maximus } & \text { L.). } & \text { Aquaculture }\end{array}$ https://doi.org/10.1016/j.aquaculture.2014.07.002

Liu, D., Wei, G., Li, T., Hu, J., Lu, N., Regenstein, J.M., Zhou, P. (2015) Effects of alkaline pretreatments and acid extraction conditions on the acid-soluble collagen from grass carp (Ctenopharyngodon idella) skin, Food Chemistry, 172 : 836-843 http://dx.doi.org/10.1016/j.foodchem.2014.09.147

Mat Jais, A.M., McCulloch, R., and Croft, K. 1994. Fatty acids and amino acids composition in Haruan as a potential role in wound healing. General Pharmacology, 25(5), 947-950. http://dx.doi.org/10.1016/0306-3623(94)90101-5Mustafa, A., Widodo, M.A., \& Kristianto, Y. (2012). Albumin and zinc content of snakehead fish 
(Channa striata) extract and its role in health. IEESE International Journal of Science and Technology, 1(2), 1-8.

Mohtar, N. F., C. O. Perera, and S. Y. Quek. 2011. Utilisation of gelatine from NZ hoki (Macruronus novaezelandiae) fish skins. International Food Research Journal.Vol.18(3): 1111-1115

Muralidharan, N., Jeya Shakila, R., Sukumar, D., and Jeyasekaran, G. 2013. Skin, bone, and muscle collagen extraction from the trash fish, leather jacket (Odonus niger) and their characterization. J. Food Sci Techno. Vol 50 (6): 1106 -1113. https://doi.org/10.1007/s13197-011-0440-y

Naeem, M., Salam, A., and Zuburi, A. 2016. Proximate composition of freshwater in relation to body size and condition factor from Pakistan. Pakistan Journal of Agricultural Sciences, 53(2), 468-476. http://dx.doi.org/10.21162/PAKJAS/16.2653

Njinkoue, J. M., Gouado, I., Tchoumbougnang, F., Yanga Ngueguim, J. H., Ndinteh, D. T., Fomogne-Fodjo, C.Y. and Schweigert, F. J. 2016. Proximate composition, mineral content and fatty acid profile of two marine fishes from Cameroonian coast: Pseudotolithus typus (Bleeker, 1863) and Pseudotolithus elongatus (Bowdich, 1825). NFS Journal. 4, 27-31. http://dx.doi.org/10.1016/j.nfs.2016.07.002 Nollet, L.M.L. (1996). Handbook of Food Analysis. Vol 1. New York, USA, Marcel Dekker Inc., $1088 \mathrm{pp}$.

Olszta, M. J., Cheng, X Jee, S. S. Kumar, R. Kim, Y. Y. Kaufman, M. J., Elliot, P. D. and Gower, L. B. (2007). Bone Structure and Formation: A new Perspective. Materials Science and Engineering: R: Reports. 58. 77-116. doi:10.1016/j.mser.2007.05.001

Patrick Saoud, I., Batal, M., Ghanawi, J., \& Lebbos, N. (2008). Seasonal evaluation of nutritional benefits of two fish species in the eastern Mediterranean Sea. International Journal of Food Science and Technology, 43, 538-542. http://dx.doi.org/10.1111/j.1365-2621.2006.01491.x

Puwastien, P., Judprasong, K., Kettwan, E., Vasanachitt, K., Nakngamanong, Y., \& Bhattacharjee, L. (1999). Proximate composition of raw and cooked Thai freshwater and marine fish. Journal of Food Composition and Analysis, 12(1), 9-16. http://dx.doi.org/10.1006/jfca.1998.0800

Paul, D. K., R. Islam and M. A. Sattar. 2013. Physico-chemical studies of lipids and nutrient contents of Channa striatus and Channa marulius. Turk. J. Fish. Aquat Sci. Vol 13, pp. 487-493.

Ramadhan, W., J. Santoso dan W. Trilaksani. 2014. Pengaruh defatting, frekuensi pencucian dan jenis dry protectant terhadap mutu tepung surimi ikan lele kering beku. J. Teknol dan Industri Pangan. Vol. 25 (1): 47-56. 
Rivas, A., Pena-Rivas, L. Ortega, E., Lopez-Martinez, C., Olea-Serrano, F., \& Lorenzo, M. L. (2014). Mineral elements contents in commercially valuable fish species in Spain. The Scientific World Journal. Scientific World Journal, 2014, 1-7. http://dx.doi.org/10.1155/2014/949364

Rosmawati, Abustam, E., Tawali, A.B., Said, M.I., and Sari, D.K. (2018). Effect of body weight on the chemical composition and collagen content of snakehead fish Channa striata skin. Fish Sci, Vol. 84 (6): 1081-1089. https://doi.org/10.1007/s12562-018$1248-8$

Salam, A. and Davies, P. M. C. 1994. Body composition of northern Pike (Esox Lucius L.) in relation to body size and condition factor. Fisheries Research. Vol 19 (3-4), 193-204. https://doi.org/10.1016/0165-7836(94)90038-8

Shim, K., Yoon, N., Lim, C., Kim, M., Kang, S., Choi, K., \& Oh, T. (2017). The relationship between Seasonal Variations in Body and Proximate Compositions Chub Mackerel Scomber japonicus from the Korea Coast. Turkish Journal of Fisheries and Aquatic Sciences, 17, 735-744. doi:10.4194/1303-2712-v17_4_09

Szpak, P. 2011. Fish bone chemistry and ultrastructure: Implications for taphonomy and stable isotope analysis. Journal of Archaeological Science, 38(12): 3358-3372. http://dx.doi.org/10.1016/j.jas.2011.07.022

Songchotikunpan, P., J. Tattiyakul and P. Supaphol.2008. Extraction and electrospinning of gelatin from fish skin. International Journal of Biological Macromolecules. Vol. 42: 247-255.

Suárez, H., Gaitán, O., \& Díaz, C. (2015). Microstructural and Physicochemical Analysis of Collagen in Intramuscular Pin Bones of Bocachico Fish (Prochilodus Sp.). Revista Colombiana de Ciencias Pecuarias, 28(2), 188-196. http://dx.doi.org/10.17533/udea.rccp.v28n2a08

Suseno, S. H., Syari, C., Zakiyah, E. R., Jacoeb, A. M., Izaki, A. F., Saraswati, and Hayati, S. 2014. Chemical Composition and Fatty Acid Profile of Small Pelagic Fish (Amblygaster sirm and Sardinella gibbosa) from Muara Angke, Indonesia. Oriental Journal of Chemistry, 30(3), 1153-1158. http://dx.doi.org/10.13005/ojc/300328

Tan, B.H., \& Azhar, M.E. (2014). Physicochemical properties and composition of Snakehead fish (Channa striatus) whole fillet powder prepared with pre-filleting freezing treatments. International Food Research Journal, 21(3), 1255-1260

Tawali, A.B., M. K. Roreng, M. Mahendradatta dan Suryani. 2012. Difusi Teknologi Produksi Konsentrat Protein dari Ikan Gabus Sebagai Food Supplement Di Jayapura. Prosiding InSINas. PG243-PG247. 
Toppe, J., Albrektsen, S., Hope, B., \& Aksnes, A. (2007). Chemical composition, mineral content and amino acid and lipid profiles in bones from various fish species. Comparative Biochemistry and Physiology, Part $B$ 146, 395-401. http://dx.doi.org/10.1016/j.cbpb.2006.11.020Wulandari, A. Supriadi dan B. Purwanto. 2013. pengaruh defatting dan suhu ekstraksi terhadap karakteristik fisik gelatin tulang ikan gabus (Channa striata). Fishtech. Vol. II (1): 38-45

Wu, G, Bazer, F. W., Burghardt, R. C., Johnson, G. A., Kom, S. W., Knabe, D. A., Li, P., Li, X., McKnight, J. R., Satterfield, M. C., \& Spencer, T. E. 2011. Proline and hydroxyproline metabolism: Implication for animal and human nutrition. Amino Acids, 40(4), 1053-1063. http://dx.doi.org/10.1007/s00726-010-0715-z

Xie S, Zhou W, Tian L, Niu J, Liu Y (2016) Effect of N-acetyl cysteine and glycine supplementation on growth performance, glutathione synthesis, anti-oxidative and immune ability of Nile tilapia, Oreochromis niloticus. Fish Shellfish Immunol, 55:233-24/ http://dx.doi.org/10.1016/j.fsi.2016.05.033

Yeannes, M. I., and Almandos, M.E. (2003). Estimation of fish proximate composition starting from water content. Food Composition and Analysis, 16(1), 81-92. http://dx.doi.org/10.1016/S0889-1575(02)00168-0

Yin T, Du H, Zhang J, and Xiong S (2016) Preparation and characterization of ultrafine fish bone powder. J Aquat Food Prod Technol 25:1045-1055

Zhang, K., Mai, K., Xu, Wi., Zhou H., Liufu Z., Zhang, Y., Peng M., and Ai, Q. 2015. Proline with or without Hydroxyproline Influences Collagen Concentration and Regulates Prolyl 4-Hydroxylase $\alpha$ (I) Gene Expression in Juvenile Turbot (Scophthalmus maximus L.). J. Ocean Univ. China. 14 (3): 541-548. DOI $10.1007 / \mathrm{s} 11802-015-2436-0$

Zuraini, A., Somchit, M.N., Solihah, M.H., Goh, Y.M., Arifah, A.K., Zakaria, M. S, Somchit, N., Rajion, M.A., Zakaria, Z.A., \& Mat Jais, A.M. (2006). Fatty acid and amino acid composition of three local Malaysian Channa spp. fish. Food Chemistry, 97, 674-678. http://dx.doi.org/10.1016/j.foodchem.2005.04.031 